\title{
Occurrence of anti-Neospora caninum and anti-Toxoplasma gondii IgG antibodies in goats and sheep in western Maranháo, Brazil
}

\author{
Ocorrência de anticorpos IgG anti-Neospora caninum e anti-Toxoplasma gondii \\ em caprinos e ovinos do oeste do Maranhão, Brasil
}

Larissa Martins de Brito Moraes'; Juliana Macedo Raimundo'; Andresa Guimarães ${ }^{1}$; Huarrisson Azevedo Santos²; Gilberto de Lima Macedo Junior ${ }^{3}$; Carlos Luiz Massard²; Rosangela Zacarias Machado'; Cristiane Divan Baldani1*

\begin{abstract}
${ }^{1}$ Departamento de Medicina e Cirurgia Veterinária - DMCV, Instituto de Veterinária, Universidade Federal Rural do Rio de Janeiro - UFRRJ

${ }^{2}$ Departamento de Parasitologia Animal - DPA, Instituto de Veterinária, Universidade Federal Rural do Rio de Janeiro - UFRRJ

${ }^{3}$ Escola de Medicina Veterinária e Zootecnia, Universidade Federal do Tocantins - UFT

${ }^{4}$ Departamento de Patologia Veterinária, Faculdade de Ciências Agrárias e Veterinárias - FCAV, Universidade Estadual Paulista - UNESP
\end{abstract}

Received March 21, 2011

Accepted July 27, 2011

\begin{abstract}
Neosporosis and toxoplasmosis are parasitic diseases which can cause reproductive problems in goats and sheep. The current study aimed to determine the occurrence of anti-Neospora caninum and anti-Toxoplasma gondii IgG antibodies in goats and sheep from the districts of Amarante do Maranhão and Buritirana, Imperatriz microregion, western area of Maranhão State, northeastern Brazil, and to assess factors associated to infection by these etiologic agents. Blood samples from 110 animals (46 goats and 64 sheep) from five herds were collected, and indirect immunofluorescence assay was used for serological testing. Of 46 goat samples, $17.39 \%(\mathrm{n}=8)$ showed anti- $N$. caninum antibodies and $4.35 \%$ $(\mathrm{n}=2)$ anti-T. gondii, while of 64 sheep samples $4.69 \%(\mathrm{n}=3)$ and $18.75 \%(\mathrm{n}=12)$ showed anti- $N$. caninum and anti-T. gondii antibodies, respectively. No significant difference regarding the presence of domestic cats and/or dogs on the property and veterinary care was seen for both etiologic agents studied. However, food supplementation and animal reproductive failure were significantly $(\mathrm{p}<0.05)$ for $N$. caninum among sheep and goats, respectively. The current study showed that goats and sheep in western Maranhão are exposed to $N$. caninum and T. gondii. It is the first evidence of these agents in small ruminants in this region.
\end{abstract}

Keywords: Toxoplasma gondii, Neospora caninum, IFAT, small ruminants.

\section{Resumo}

A neosporose e a toxoplasmose são doenças parasitárias que podem causar problemas reprodutivos em caprinos e ovinos. O objetivo deste estudo foi determinar a ocorrência de anticorpos IgG anti-Neospora caninum e antiToxoplasma gondii em caprinos e ovinos dos municípios de Amarante do Maranhão e Buritirana, microrregiáo de Imperatriz, Oeste maranhense, Nordeste do Brasil, bem como avaliar fatores associados à infecçáo por esses agentes etiológicos. Amostras de sangue de 110 animais (46 caprinos e 64 ovinos), provenientes de cinco propriedades, foram coletadas, e a reação de imunofluorescência indireta utilizada para o diagnóstico sorológico. Das 46 amostras de caprinos, $17,39 \%(\mathrm{n}=8)$ apresentaram anticorpos anti- $N$. caninum e 4,35\% $(\mathrm{n}=2)$ anti- $T$. gondii, enquanto das 64 amostras de ovinos, 4,69\% $(\mathrm{n}=3)$ e $18,75 \%(\mathrm{n}=12)$ apresentaram anticorpos anti- $N$. caninum e anti-T. gondii, respectivamente. Não houve diferença significativa, considerando-se a presença de gato e/ou cáo na propriedade e assistência veterinária para ambos os agentes estudados. Entretanto, suplementação alimentar e presença de animais com

\footnotetext{
${ }^{*}$ Corresponding author: Cristiane Divan Baldani

Laboratório de Patologia Clínica, Departamento de Medicina e Cirurgia Veterinária, Instituto de Veterinária, Universidade Federal Rural do Rio de Janeiro - UFRRJ,

Rod. BR 465, Km 47, CEP 23890-000, Seropédica, RJ, Brazil

e-mail: crisbaldani@ufrrj.br
} 
problemas reprodutivos diferiram significativamente $(\mathrm{p}<0,05)$ em ovinos e caprinos, respectivamente. Os resultados do presente estudo demonstraram que caprinos e ovinos, da região Oeste do Maranhão são expostos aos coccídios $N$. caninum e T. gondii. Essa é a primeira evidência desses agentes em pequenos ruminantes nessa região.

Palavras-chave: Toxoplasma gondii, Neospora caninum, RIFI, pequenos ruminantes.

\section{Introduction}

Neospora caninum is an intracellular apicomplexan protozoan parasite that belongs to the family Sarcocystidae. This agent was first described and characterized in dogs in the United States, and it has been described in several species such as small ruminants. This parasite is characterized by three stages of infection: sporozoites inside oocysts that are eliminated in the feces of definitive hosts, and tachyzoites and bradyzoites inside tissue cysts of intermediate hosts (DUBEY et al., 2002). Animals are born seronegative and become infected after ingesting water and food contaminated by oocysts. This coccidian parasite can have goats and sheep as intermediate hosts and can cause serious reproductive problems in these animals (MODOLO et al., 2008a). It is a common cause of abortion, resulting in decreased productivity and consequently economic losses. Dogs play an important role as intermediate and definitive hosts (DUBEY, 1999).

Toxoplasma gondii is also an obligatory intracellular coccidian protozoan parasite, and although it has similar morphology and biology to N. caninum, it is antigenically distinct (DUBEY, 2003). Its definitive hosts are members of the Felidae family, and domestic cats play an important role in toxoplasmosis epidemiology through contamination of pastures and water with oocysts eliminated in their feces (HILL; DUBEY, 2002; MOTTA et al., 2008). This protozoan may have goats and sheep as intermediate hosts (DUBEY, 1990). It can cause serious reproductive problems and is a major cause of abortion (MUNDAY; MASON, 1979; UNDERWOOD; ROOK, 1992).

Toxoplasmosis is one of the most common parasitic diseases worldwide, and goats and sheep infected with $T$. gondii are an important source of infection as consumption of raw meat and milk may infect humans (MODOLO et al., 2008b). Humans can also become infected when they eat undercooked meat with tissue cysts, consume contaminated food or drink and accidentally ingest oocysts from the environment (DUBEY, 2009). Although most infections in humans are asymptomatic, this parasite can sometimes cause a devastating disease (HILL; DUBEY, 2002).

Brazil is the eighth leading producer of small ruminants in the world, with a herd over 30 million animals (EMBRAPA, 2011). The great demand for meat and milk from goats and sheep in developing countries due to population growth, urbanization and changes in food preferences and consumers habits has contributed for increased production in Brazil.

According to the Brazilian Ministry of Agriculture, Livestock and Food Supply (MAPA, 2005), the flock of goats and sheep in Brazil comprises to $10,307,000$ and 15,588,000 animals respectively, which are constantly growing. In the state of Maranháo, northeastern Brazil, goat and sheep herds are mainly concentrated in the east, north and west regions, corresponding to almost $80 \%$ of the state. These small ruminants are economically important in that region, and are a major source of meat and milk for human consumption and an important source of income for landowners.

In view of the growing importance of sheep and goats in Brazil and potential economic losses due to neosporosis and toxoplasmosis, the current study aimed to determine the occurrence of anti- N. caninum and anti-T. gondii $\operatorname{IgG}$ antibodies in goats and sheep from the western area of Maranhão and to describe the farm and herd characteristics associated.

\section{Materials and Methods}

The study was conducted in the western area of Maranhão State, Imperatriz microregion, in the districts of Amarante do Maranhão (05 34' $08^{\prime \prime} S$ and $\left.46^{\circ} 44^{\prime} 15^{\prime \prime} \mathrm{W}\right)$ and Buritirana $\left(05^{\circ} 35^{\prime} 55^{\prime \prime} \mathrm{S}\right.$ and $\left.47^{\circ} 00^{\prime} 59^{\prime \prime} \mathrm{W}\right)$, which extend over 7,669,090 $\mathrm{km}^{2}$ and $818,416 \mathrm{~km}^{2}$, respectively. Maranhão is the northeastern region of Brazil, in a transition zone of semi-arid climate of inland Northeast to the humid equatorial Amazon (MONTES, 1997).

For determining the occurrence of anti- $N$. caninum and anti- $T$. gondii antibodies, a total of 110 animals (46 goats, of which 29 females and 17 males, and 64 sheep, of which 59 females and 5 males) were selected from five farms through non-probabilisty convenience sampling. Farms were selected based on owner's agreement and easy access to blood collection. All owners participating signed a free consent form which clarified the objectives of the study. Female animals predominated in all the farms $(88 / 110)$ as animals were destined for meat production. Blood samples were collected from apparently healthy sheep and goats by jugular venipuncture and drawn into vacuum tubes without anticoagulant. The samples were stored at a cooler with ice and sent to the Laboratory of Clinical Pathology of the Universidade Federal do Tocantins, Escola de Medicina Veterinária e Zootecnia. After clot retraction, samples were submitted to centrifugation at 3,000 rpm for 10 minutes. The resulting serum was stored at $-20{ }^{\circ} \mathrm{C}$ until serological testing.

Epidemiological questionnaires were applied to each farm owner to collect data on general characteristics of the herd, management system, sanitary care, reproductive problems, and presence of domestic cats or dogs according to Thrusfield (2004).

Detection of anti- $N$. caninum and anti-T. gondii IgG antibodies were performed at Universidade Federal Rural do Rio de Janeiro, Institute of Veterinary, by indirect immunofluorescence assay (IFAT), as previously described by Mineo (2007) and Camargo (1973), respectively. Antigens were supplied by the Laboratory of Immunoparasitology of the Universidade Estadual Paulista, Faculdade de Ciências Agrárias e Veterinárias. Tachyzoites of $N$. caninum (Nc-1 strain) maintained by continuous passages in cultures of Vero cells and T. gondii (RH strain) tachyzoites 
obtained by intraperitoneal serial passages in Swiss mice were used as antigens. A cutoff dilution of 1:25 and 1:40 were used for $N$. caninum and $T$. gondii, respectively. In each IFAT reaction, previously established positive and negative serum samples were included as controls and a FITC-conjugated monoclonal antigoat/sheep IgG (Sigma-Aldrich F F137) secondary antibody was used. The reactions were visualized under an immunofluorescence microscope, and were considered positive when tachyzoites showed complete peripheral apple green fluorescence, and size, appearance and density of staining were compared against a positive control. The negative reaction showed a uniform red counter stain.

The statistical analysis was performed using Fisher's exact test with 95\% confidence intervals and an estimation error of 0.05 . Serology results were associated with variables related to species and information collected in the questionnaire.

\section{Results}

Among the 110 sera analyzed, 10\% (11/110) showed anti- $N$. caninum and $12.73 \%$ (14/110) anti-T. gondii IgG antibodies. Only one of the properties had no serologically positive animal for $T$. gondii, while three properties were negative for $N$. caninum. The seropositive rate among the five properties studied varied from 0 to $26.66 \%$ for $N$. caninum and 0 to $21.43 \%$ for $T$. gondii.

Regarding goats, $17.39 \%$ (8/46) were seropositive for $N$. caninum and $4.35 \%$ (2/46) for T. gondii. On the other hand, 4.69\% (3/64) of the sheep showed anti- $N$. caninum and $18.75 \%(12 / 64)$ anti-T. gondii IgG antibodies. The simultaneous presence of specific antibodies for $N$. caninum and $T$. gondii was found in only one female sheep.

No significant difference was found regarding the presence of domestic cats and/or dogs on the property and veterinary care for both etiologic agents studied. However, significant differences were found regarding food supplementation and animal reproductive failure for $N$. caninum among sheep and goats, respectively $(\mathrm{p}<0.05)$ (Table 1$)$.

\section{Discussion}

In the current study the occurrence of antibodies against $N$. caninum and $T$. gondii in goats and sheep was investigated by IFAT. The study results showed these ruminants are exposed to both protozoan parasites in the western area of Maranhão, and to the authors' best knowledge this is the first report about the occurrence of anti-N. caninum and anti-T. gondii IgG antibodies in goats and sheep in this region.

The frequency of anti- $N$. caninum $\mathrm{IgG}$ antibodies in goats in this study was $17.39 \%(8 / 46)$, similar to that reported by Uzêda et al. (2007) in the northeastern state of Bahia, where 15\% (58/384) of the goats had specific anti-N. caninum IgG antibodies and by Modolo et al. (2008a) in the southeastern state of São Paulo where $19.77 \%$ (161/923) were seropositive. However, Lima et al. (2008) in Mossoró, northeastern state of Rio Grande do Norte, reported that only $1.05 \%$ (4/381) of goats were seropositive, but as in our study no significant association with presence of dogs ( $p>0.05)$ was observed. Otherwise, Faria et al. (2007) in the northeastern state of Paraíba and Figliuolo et al. (2004a) in São Paulo reported that only 3.3\% (10/306) and 6.4\% (25/394) of the animals, respectively, were seropositive. According to Ueno et al. (2009) it is not easy to compare frequencies of infections between regions as the studies use different serological tests, cutoff values and sampling methods. Differences in seropositivity between regions within a single country can be explained by different climate conditions that interfere with the maintenance and viability of oocysts in the environment, as well as different types of sanitary management and animal sampled (GEORGIEVA et al., 2006). It should be mentioned that goat herds were restricted to smaller areas in the farms, where animal density tends to be higher and therefore can facilitate the access of dogs to carcasses of infected animals, aborted fetuses or placenta. Indeed, Faria et al. (2010) reported that animals raised on properties of less than 30 ha in size are more likely to become infected by $N$. caninum. There was found association between animal reproductive failure and

Table 1. Frequency of Neospora caninum and Toxoplasma gondii IgG antibodies in goats and sheep from the western area of Maranhão State, Brazil, detected by indirect immunofluorescence assay (IFAT), and different risk factors associated.

\begin{tabular}{|c|c|c|c|c|c|c|c|c|c|}
\hline \multirow[t]{3}{*}{ Risk factors } & & \multicolumn{4}{|c|}{ Goats $(n=46)$} & \multicolumn{4}{|c|}{ Sheep $(n=64)$} \\
\hline & & \multicolumn{2}{|c|}{ Neospora caninum } & \multicolumn{2}{|c|}{ Toxoplasma gondii } & \multicolumn{2}{|c|}{ Neospora caninum } & \multicolumn{2}{|c|}{ Toxoplasma gondii } \\
\hline & & Positive & Negative & Positive & Negative & Positive & Negative & Positive & Negative \\
\hline \multirow[t]{2}{*}{ Presence of cats } & Yes & $8^{a}$ & $38^{a}$ & $2^{a}$ & $44^{a}$ & $3^{a}$ & $61^{a}$ & $12^{a}$ & $52^{a}$ \\
\hline & No & $0^{a}$ & $0^{a}$ & $0^{a}$ & $0^{a}$ & $0^{a}$ & $0^{a}$ & $0^{\mathrm{a}}$ & $0^{a}$ \\
\hline \multirow[t]{2}{*}{ Presence of dogs } & Yes & $8^{a}$ & $38^{a}$ & $2^{a}$ & $44^{a}$ & $3^{a}$ & $61^{a}$ & $12^{\mathrm{a}}$ & $52^{a}$ \\
\hline & No & $0^{a}$ & $0^{\text {a }}$ & $0^{\text {a }}$ & $0^{a}$ & $0^{a}$ & $0^{a}$ & $0^{\text {a }}$ & $0^{a}$ \\
\hline \multirow[t]{2}{*}{ Food supplementation } & Yes & $8^{a}$ & $38^{a}$ & $2^{a}$ & $44^{a}$ & $0^{a}$ & $44^{a}$ & $8^{a}$ & $36^{a}$ \\
\hline & $\mathrm{No}$ & $0^{a}$ & $0^{\mathrm{a}}$ & $0^{a}$ & $0^{a}$ & $3^{b}$ & $17^{b}$ & $4^{a}$ & $16^{\mathrm{a}}$ \\
\hline \multirow[t]{2}{*}{ Veterinary care } & Yes & $8^{a}$ & $38^{a}$ & $2^{a}$ & $44^{a}$ & $3^{a}$ & $61^{a}$ & $12^{\mathrm{a}}$ & $52^{a}$ \\
\hline & No & $0^{a}$ & $0^{a}$ & $0^{\mathrm{a}}$ & $0^{a}$ & $0^{a}$ & $0^{a}$ & $0^{\mathrm{a}}$ & $0^{a}$ \\
\hline \multirow{2}{*}{$\begin{array}{l}\text { Animal reproductive } \\
\text { problems }\end{array}$} & Yes & $8^{a}$ & $22^{a}$ & $0^{\mathrm{a}}$ & $30^{a}$ & $3^{a}$ & $61^{a}$ & $12^{a}$ & $52^{a}$ \\
\hline & No & $0^{\mathrm{b}}$ & $16^{\mathrm{b}}$ & $2^{a}$ & $14^{\mathrm{a}}$ & $0^{\mathrm{a}}$ & $0^{\text {a }}$ & $0^{\mathrm{a}}$ & $0^{a}$ \\
\hline
\end{tabular}

Frequencies in columns followed by the same letter do not differ by Fisher's exact test ( $\mathrm{p}>0.05$ ) and frequencies in columns followed by different letter differ by Fisher's exact test $(\mathrm{p}<0.05)$. 
anti- $N$. caninum antibodies in goats $(\mathrm{p}<0.05)$ (Table 1$)$, which is consistent with that reported by Uzêda et al. (2007). However, Modolo et al. (2008a) and Lima et al. (2008) did not find this association. Further studies are needed in this region. Additionally, the scarcity of data on the occurrence of $N$. caninum in goats is a factor that prevents comparisons between different Brazilian regions.

The occurrence of anti- $T$. gondii IgG antibodies in goats in the western area of Maranhão was 4.35\% (2/46), which is lower than that reported in most studies. Several studies carried out in Brazil have reported frequencies of anti- $T$. gondii antibodies in goats ranging from $14.47 \%$ to $28.7 \%$ (MAINARDI et al., 2000; FIGLIUOLO et al., 2004a; FARIA et al., 2007; CAVALCANTE et al., 2008; LIMA et al., 2008; MODOLO et al., 2008b). However, most reports are from goat herds located in areas with different climate conditions than that of Maranhão. Therefore, similar to that seen for anti- $N$. caninum antibodies, the differences are probably due to environment conditions (DUBEY, 1990; SAWADOGO et al., 2005), breeding conditions and possibly diagnostic methods and cutoffs used (BJÖRKMAN; UGGLA, 1999). It should be mentioned, however, that the results of the current study are in accordance with those reported by Nieto and Meléndez (1998) in the Lara State, Venezuela, where the seroprevalence was 5.9\% (26/438). Moreover, in the current study, goats were maintained under an extensive management system and destined for meat production, which due to their own characteristics reduces the likelihood of infection compared to intensive management system and dairy properties (SILVA et al., 2003; MACHADO; LIMA, 1987). Although the prevalence of $T$. gondii antibodies in goats from western Maranhão is low, human infection is still likely through consumption of raw or undercooked meat with cysts or milk containing $T$. gondii tachyzoites, as well as economic losses caused by toxoplasmosis in the herd (PÉPIN et al., 1997; CHIARI; NEVES, 1984).

Of all 64 sheep studied, three animals (4.69\%) tested positive for anti-N. caninum IgG antibodies. Similar results were reported by Špilovská et al. (2009) in Slovakia and Vogel et al. (2006) in a study performed in Rio Grande do Sul, southern Brazil, where 3.7\% (14/382) and 3.2\% (2/62) sheep were seropositive, respectively. In Mossoró, Rio Grande do Norte, northeastern Brazil, the positive rate reported by Soares et al. (2009) was also low (1.8\%; 7/409). Frequencies of $9.2 \%$ (55/597), 9.5\% (29/305) and 9.6\% (33/343) were reported in São Paulo (FIGLIUOLO et al., 2004b), Paraná (ROMANELLI et al., 2007) and Alagoas (FARIA et al., 2010), respectively. Ueno et al. (2009) in the Federal District, centralwest Brazil, and Salaberry et al. (2010), in Uberlândia, Minas Gerais, reported that $8.81 \%(90 / 1,028)$ and $8.1 \%(27 / 334)$ of sheep had anti- $N$. caninum IgG antibodies, respectively. Although comparisons of frequencies of infection between regions are difficult, several authors using IFAT as diagnostic test and higher cutoff than that used in the current study, reported higher frequencies (FARIA et al., 2010; FIGLIUOLO et al., 2004b; ROMANELLI et al., 2007), suggesting that differences could be due to different sampling methods. Indeed, there is great variability of results regarding the region studied (SALABERRY et al., 2010). Rossi et al. (2011) in a study of neosporosis in Minas Gerais using different serological methods suggested that variations among frequency rates may also be due to different environment contamination. The results of the current study could also be attributed to the extensive management system of the animals, evidencing low technical level of sheep production, which is in agreement with data reported by Faria et al. (2010). In addition, the results can vary according to the extent of canine presence and animal age. Although no significant association between the presence of dogs and $N$. caninum infection was found ( $\mathrm{p}>0.05$ ), Al-Majali et al. (2008) identified the presence of more than one dog in the herd as a risk factor for neosporosis. In the current study, seropositivity was correlated with lack of supplementation $(\mathrm{p}<0.05)$ (Table 1), which has been reported to be a risk factor for T. gondii infections in sheep (LOPES et al., 2010). It is noteworthy that anti- $N$. caninum IgG antibodies were detected in animals from only two properties, which do not rule out the possibility of a local problem that is not representative of this particular region or species.

The occurrence of anti- $T$. gondii IgG antibodies in sheep in the western area of Maranhão was $18.75 \%$ (12/64). Similar frequencies were reported by Pita Gondim et al. (1999) in Bahia and by Ragozo et al. (2008) in Sáo Paulo where 18.75\% (45/240) and $24.2 \%$ (120/495) of sheep had anti- $T$. gondii antibodies, respectively. In Curitiba, Paraná, 25.75\% (43/167) of sheep were also seropositive (THOMAZ-SOCCOL et al., 2009). Higher frequencies were reported by other authors. In Paraná, Romanelli et al. (2007) demonstrated a $51.5 \%(157 / 305)$ prevalence of $T$. gondii in the sheep studied. Lopes et al. (2010), in the Jaboticabal microregion, São Paulo, found T. gondii-specific antibodies in 52.05\% (254/488) of the animals. Also in São Paulo, Figliuolo et al. (2004b) reported that 34.7\% (207/597) of the sheep were seropositive for T. gondii. Ueno et al. (2009) in the Federal District, reported that 38.22\% $(364 / 1,028)$ of the sheep had anti-T. gondii IgG antibodies. The results of the current study could be explained in part due to the extensive management system of animals as sheep raised in this system are more likely to be exposed to oocysts (WALTNERTOEWS et al., 1991; LOPES et al., 2010), although no significant association was seen between seroprevalence of $T$. gondii and the presence of cats in the herds. And lack of mineral supplementation, which was also identified as a risk factor (LOPES et al., 2010), could also contribute to the seropositive rate seen in the current study. Differences in geographical area and climate, animal management and serological techniques used should also be considered.

It is noteworthy that a higher rate of $T$. gondii infection compared to $N$. caninum in sheep has also been reported in other studies (AGUIAR et al., 2004; FIGLIUOLO et al., 2004b; ROMANELLI et al., 2007). According to Ueno et al. (2009), it may be attributed to differences in host susceptibility to each parasite. No significant difference was found regarding the presence of domestic cats and/or dogs on the property and veterinary care for both etiologic agents studied (Table 1). Similar results were reported by Soares et al. (2009) and Faria et al. (2010) in the state of Rio Grande do Norte and Alagoas, although it should be pointed out that there may be a potential effect on the reproductive life of seropositive animals. However, in the state of São Paulo, Figliuolo et al. (2004a) reported an association between the presence of dogs and $N$. caninum infection. No significant association between the presence of cat in the herds and seroprevalence of toxoplasmosis has also been reported by Lima et al. (2008) in 
Rio Grande do Norte and Figliuolo et al. (2004b). Yet, cat access to pasture has been identified as a risk factor by Romanelli et al. (2007) in Paraná and Lopes et al. (2010) in São Paulo suggesting that the presence of or close exposure to feline species is a major factor in the epidemiology of toxoplasmosis.

Our data showed that goats and sheep in the western area of Maranhão are exposed to the protozoa $N$. caninum and T. gondii. It is the first evidence of these agents in goats and sheep in this region. Control measures and sanitary education in this region are needed to educate breeders about these diseases, prevent reproductive problems, and thus avoid compromising production and goat and sheep breeding. Nevertheless, special attention is needed to prevent compromising human health. Further investigations involving a larger number of animals are required to better understand infection by these agents in the region studied, and the actual role played by toxoplasmosis and neosporosis on reproductive and economic losses in ruminants in Maranhão.

\section{References}

AGUIAR, D. M. et al. Prevalência de anticorpos anti-Neospora caninum em ovinos do município de Monte Negro, RO, Amazônia ocidental brasileira. Arquivos do Instituto Biológico, v. 71, p. 616-618, 2004.

AL-MAJALI, A. M. et al. Neosporosis in sheep and different breeds of goats from Southern Jordan: prevalence and risk factors analysis. American Journal of Animal and Veterinary Sciences, v. 3, n. 2, p. 47-52, 2008. http://dx.doi.org/10.3844/ajavsp.2008.47.52

BJÖRKMAN, C.; UGGLA, A. Serological diagnosis of Neospora caninum infection. International Journal for Parasitology, v. 29, n. 10 , p. $1497-1507,1999$. http://dx.doi.org/10.1016/S00207519(99)00115-0

BRASIL. Ministério da Agricultura, Pecuária e Abastecimento MAPA. 2005. Disponível em: <http://www.agricultura.gov.br/>. Acesso em: 21 dez. 2010.

CAMARGO, M. E. Introduçáo às técnicas de Imunofluorescência. São Paulo: Instituto de Medicina Tropical, 1973. p. 89-91.

CAVALCANTE, A. C. R. et al. Risk factors for infection by Toxoplasma gondii in herds of goats in Ceará, Brazil. Arquivo Brasileiro de Medicina Veterinária e Zootecnia, v. 60, n. 1, p. 36-41, 2008. http://dx.doi. org/10.1590/S0102-09352008000100006

CHIARI, C. A.; NEVES, D. P. Toxoplasmose humana adquirida através da ingestão de leite de cabra. Memórias do Instituto Oswaldo Cruz, v. 79, n. 3, p. 337-340, 1984. http://dx.doi.org/10.1590/S007402761984000300007

DUBEY, J. P. Status of toxoplasmosis in sheep and goats in the United States. Journal of the American Veterinary Medical Association, v. 196, n.2, p. 259-262, 1990. PMid:2404925.

DUBEY, J. P. Recent advances in Neospora and neosporosis. Veterinary Parasitology, v. 84, n. 3-4, p. 349-367, 1999. http://dx.doi.org/10.1016/ S0304-4017(99)00044-8

DUBEY, J. P. et al. Redescription of Neospora caninum and its differentiation from related coccidia. International Journal for Parasitology, v. 32, n. 8, p. 929-946, 2002. http://dx.doi.org/10.1016/ S0020-7519(02)00094-2
DUBEY, J. P. Review of Neospora caninum and Neosporosis in animals. Korean Journal of Parasitology, v. 41, n. 1, p. 1-16, 2003. PMid:12666725. PMCid:2717477. http://dx.doi.org/10.3347/ kjp.2003.41.1.1

DUBEY, J. P. Toxoplasmosis in sheep: The last 20 years. Veterinary Parasitology, v. 163, n. 1-2, p. 1-14, 2009. PMid:19395175. http://dx.doi.org/10.1016/j.vetpar.2009.02.026

EMBRAPA. Embrapa caprinos e ovinos. Desenvolvimento de queijos de coalho de leite de cabra adicionados de ervas e frutas obtidas da biodiversidade do semi-árido brasileiro. Embrapa. Disponível em: <http://saanen.cnpc.embrapa.br>. Acesso em: 9 fev. 2011.

FARIA, E. B. et al. Prevalence of anti-Toxoplasma gondii and anti-Neospora caninum antibodies in goats slaughtered in the public slaughterhouse of Patos city, Paraíba State, Northeast region of Brazil. Veterinary Parasitology, v. 149, p. 126-129, 2007. PMid:17706359. http://dx.doi. org/10.1016/j.vetpar.2007.07.009

FARIA, E. B. et al. Risk factors associated with Neospora caninum seropositivity in sheep from the State of Alagoas, in the Northeast region of Brazil. Journal of Parasitology, v. 96, n. 1, p. 197-199, 2010. PMid:19799489. http://dx.doi.org/10.1645/GE-2176.1

FIGLIUOLO, L. P. C. et al. Prevalence of anti-Toxoplasma gondii and anti-Neospora caninum antibodies in goat from São Paulo State, Brazil. Small Ruminant Research, v. 55, n. 1-3, p. 29-32, 2004a. http://dx.doi. org/10.1016/j.smallrumres.2003.12.013

FIGLIUOLO, L. P. C. et al. Prevalence of anti-Toxoplasma gondii and anti-Neospora caninum antibodies in ovine from São Paulo State, Brazil. Veterinary Parasitology, v. 123, n. 3-4, p. 161-166, 2004 b. PMid:15325042. http://dx.doi.org/10.1016/j.vetpar.2004.06.006

GEORGIEVA, D. A.; PRELEZOV, P. N.; KOINARSKI, V. Neospora caninum and neosporosis in animals - A review. Bulgarian Journal of Veterinary Medicine, v. 9, n. 1, p. 1-26, 2006.

HILL, D.; DUBEY, J. P. Toxoplasma gondii: transmission, diagnosis and prevention. Clinical Microbiology and Infection, v. 8, n. 10, p. 634-640, 2002. PMid:12390281. http://dx.doi.org/10.1046/j.14690691.2002.00485.x

LIMA, J. T. R. et al. Prevalência de anticorpos anti-Toxoplasma gondii e anti-Neospora caninum em rebanhos caprinos do município de Mossoró, Rio Grande do Norte. Brazilian Journal of Veterinary Research and Animal Science, v. 45, n. 2, p. 81-86, 2008.

LOPES, W. D. Z. et al. Seroprevalence of and risk factors for Toxoplasma gondii in sheep raised in the Jaboticabal microregion, Sáo Paulo State, Brazil. Research in Veterinary Science, v. 88, n.1, p. 104-106, 2010. PMid:19589550. http://dx.doi.org/10.1016/j.rvsc.2009.06.006

MACHADO, T. M. M.; LIMA, J. D. Frequência de anticorpos anti-Toxoplasma gondii em caprinos criados sob diferentes formas de exploração no estado de Minas Gerais. Arquivo Brasileiro de Medicina Veterinária e Zootecnia, v. 55, p. 485-487, 1987.

MAINARDI, R. S. et al. Soroprevalência de Toxoplasma gondii em rebanhos caprinos no estado de Sáo Paulo. Revista Brasileira de Parasitologia Veterinária, v. 9, n. 2, p. 97-99, 2000.

MINEO, T. W. P. Estudo da resposta imune celular e humoral de cães frente à infecçáo oral por Neospora caninum. 2007. $171 \mathrm{f}$. Tese (Doutorado em Medicina Veterinária)-Universidade Estadual Paulista, São Paulo.

MODOLO, J. R. et al. Freqüência de anticorpos anti-Neospora caninum em soros de caprinos do estado de Sáo Paulo e sua relaçáo com o manejo 
dos animais. Pesquisa Veterinária Brasileira, v. 28, n. 12, p. 597-600, 2008a. http://dx.doi.org/10.1590/S0100-736X2008001200006

MODOLO, J. R. et al. Avaliação da ocorrência de anticorpos antiToxoplasma gondii, em soros de caprinos do estado de São Paulo, e associação com variáveis epidemiológicas, problemas reprodutivos e riscos à saúde pública. Pesquisa Veterinária Brasileira, v. 28, n. 12, p. 606-610, 2008b. http://dx.doi.org/10.1590/S0100-736X2008001200008

MONTES, L. M. Zoneamento Geoambiental do Estado do Maranhão. IBGE, 1997. Disponível em: <http://www.ibge.gov.br/ home/>. Acesso em: $21 \mathrm{dez} .2010$.

MOTTA, A. C. et al. Aborto em ovinos associado à toxoplasmose: Caracterização sorológica, anátomo-patológica e imunoistoquímica. Revista Brasileira de Parasitologia Veterinária, v. 17, p. 204-208, 2008. Suplemento 1 .

MUNDAY, B. L.; MASON, R. W. Toxoplasmosis as a cause of perinatal death in goats. Australian Veterinary Journal, v. 55, n. 10, p. 485-487, 1979. PMid:539933. http://dx.doi.org/10.1111/j.1751-0813.1979. tb00375.x

NIETO, S. O.; MELÉNDEZ, R. D. Seroprevalence of Toxoplasma gondii in goats from arid zones of Venezuela. Journal of Parasitology, v. 84, n. 1, p. 190-191, 1998. PMid:9488366. http://dx.doi.org/10.2307/3284559

PÉPIN, M.; RUSSO, P.; PARDON, P. Public health hazards from small ruminant meat products in Europe. Revue Scientifique et Technique, v. 16, n. 2, p. 415-425, 1997.

PITA GONDIM, L. F. et al. Serological survey of antibodies to Toxoplasma gondii in goats, sheep, cattle and water buffaloes in Bahia State, Brazil. Veterinary Parasitology, v. 82, n. 4, p. 273-276, 1999. http://dx.doi.org/10.1016/S0304-4017(99)00033-3

RAGOZO, A. M. A. et al. Seroprevalence and isolation of Toxoplasma gondii from sheep from São Paulo State, Brazil. Journal of Parasitology, v. 94, n. 6, p. 1259-1263, 2008. PMid:18576886. http://dx.doi. org/10.1645/GE-1641.1

ROMANELLI, P. R. et al. Prevalence of Neospora caninum and Toxoplasma gondii in sheep and dogs from Guarapuava farms, Paraná State, Brazil. Research in Veterinary Science, v. 82, n. 2, p. 202-207, 2007. PMid:17266999. http://dx.doi.org/10.1016/j.rvsc.2006.04.001

ROSSI, G. F. et al. Evaluation of Toxoplasma gondii and Neospora caninum infections in sheep from Uberlândia, Minas Gerais State, Brazil, by different serological methods. Veterinary Parasitology, v. 175, n. 3-4, p. 252-259, 2011.
SALABERRY, S. R. S. et al. Prevalence of Neospora caninum antibodies in sheep flocks of Uberlândia county, MG. Revista Brasileira de Parasitologia Veterinária, v. 19, n. 3, p. 148-151, 2010. PMid:20943017.

SAWADOGO, P. et al. Seroprevalence of $T$. gondii in sheep from Marrakech, Morocco. Veterinary Parasitology, v. 130, n. 1-2, p. 89-92, 2005. PMid:15893074. http://dx.doi.org/10.1016/j. vetpar.2005.03.025

SILVA, A. V. et al. Toxoplasmose em ovinos e caprinos: estudo soroepidemiológico em duas regiōes do Estado de Pernambuco, Brasil. Ciência Rural, v. 33, n. 1, p. 115-119, 2003. http://dx.doi.org/10.1590/ S0103-84782003000100018

SOARES, H. S. et al. Prevalence of anti-Toxoplasma gondii and antiNeospora caninum antibodies in sheep from Mossoró, Rio Grande do Norte, Brazil. Veterinary Parasitology, v. 160, n. 3-4, p. 211-214, 2009. PMid:19091473. http://dx.doi.org/10.1016/j.vetpar.2008.10.102

ŠPILOVSKÁ, S. et al. The first finding of Neospora caninum and the occurrence of other abortifacient agents in sheep in Slovakia. Veterinary Parasitology, v. 164, p. 320-323, 2009. PMid:19540672. http://dx.doi. org/10.1016/j.vetpar.2009.05.020

THOMAZ-SOCCOL, V. et al. Ocorrência de anticorpos anti-Toxoplasma gondii em ovinos das áreas urbanas e periurbanas de Curitiba, Paraná. Revista Brasileira de Parasitologia Veterinária, v. 18, p. 69-70, 2009. Suplemento 1.

THRUSFIELD, M. Epidemiologia veterinária. 2. ed. São Paulo: Roca, 2004. 556 p.

UENO, T. E. H. et al. Prevalence of Toxoplasma gondii and Neospora caninum infections in sheep from Federal District, central region of Brazil. Tropical Animal Health and Production, v. 41, n. 4, p. 547-552, 2009. PMid:18726165. http://dx.doi.org/10.1007/s11250-008-9220-8

UNDERWOOD, W. J.; ROOK, J. S. Toxoplasmosis infection in sheep. The Compendium on Continued Education in Veterinary Practice, v. 14, n. 8, p. 1543-1549, 1992.

UZÊDA, R. S. et al. Seroprevalence of Neospora caninum in dairy goats from Bahia, Brazil. Small Ruminant Research, v. 70, n. 2-3, p. 257-259, 2007. http://dx.doi.org/10.1016/j.smallrumres.2006.04.003

VOGEL, F. S. F.; ARENHART, S.; BAUERMANN, F. V. Anticorpos anti-Neospora caninum em bovinos, ovinos e bubalinos no Estado do Rio Grande do Sul. Ciência Rural, v. 36, n. 6, p. 1948-1951, 2006. http://dx.doi.org/10.1590/S0103-84782006000600048

WALTNER-TOEWS, D.; MONDESIRE, R.; MENZIES, P. The seroprevalence of Toxoplasma gondii in Ontario sheep flocks. Canadian Veterinary Journal, v. 32, n. 12, p. 734-737, 1991. 